\title{
Training International Commercial Lawyers through Participation in the Willem C. Vis Moot
}

\author{
BAN Xiaohui \\ Assistant professor \\ Law School \\ Wuhan University \\ XIAO Yongping \\ Director, professor \\ Institute of International Law \\ Wuhan University
}

\section{Introduction}

With China's increasing involvement in the international community, the demand for lawyers capable of dealing with international disputes is rising sharply. China is opening up in a comprehensive way and goes out of the country to make investment. Chinese law schools have to catch up with the demand from society and train legal talents with an international orientation. Wuhan University Law School is taking the lead in training international commercial lawyers with amazing achievements. Wuhan University has found an effective way of training international commercial elite lawyers by participation in the Willem $C$ Vis International Commercial Arbitration Moot (hereinafter referred to as "the Moot"). This paper introduces the Moot shortly, traces the achievement of Wuhan University Law School in the Moot, introduces the training process at Wuhan University Law School, and concludes that the Moot is an effective way of training international commercial lawyers which should be further promoted.

\section{The Moot}

The Willem C Vis International Commercial Arbitration Moot (hereinafter referred to as "the Moot") originated from the idea to attract law students to study the United Nations Convention on Contracts for the International Sale of Goods (CISG) and international commercial arbitration. ${ }^{1}$ The Moot comprises both written memoranda and oral arguments and that the oral arguments would take place in Vienna. A real-world-like case involving contractual disputes and arbitration procedures is released in every October. Students submit memoranda for claimants, afterwards receive assigned claimant memoranda of other participants, and write memoranda for defendants in response to the claimant memoranda received. The oral hearing takes in Vienna, as well as in Hong Kong and other places around the world known as pre-moots. The Moot may be the most successful moot with 290 registered teams in the 2013-2014 Moot in Vienna.

The distinct feature of the Moot is to teach substantive law through writing and teaching law, legal skills and legal culture. ${ }^{2}$ The distinct feature of the Moot is its real-world-like sense. It presents real-world-like cases to law students for students to represent both parties before an arbitral tribunal. The whole process is innovative compared with conventional law school teaching of theories and legal rules in textbooks.

Students have to learn the facts, and discover further facts by requesting clarifications of the problem, identify the legal issues, write memoranda for both parties, and represent the parties before arbitrators. All the legal knowledge, legal skills and other skills required of a professional lawyer can be developed through participation of the Moot. It is suggested by an American Bar Association Task Force report that the fundamental layering skills can be acquired through participation in the Moot: problem solving, legal analysis, legal research, factual

\footnotetext{
${ }^{1}$ Eric E. Bergsten, Teaching about International Commercial Law and Arbitration: the Eighth Annual Willem C. Vis International Commercial Arbitration Moot, 18 J. of Int'l Arb. 481 (2001), 481.

${ }^{2}$ Mark R. Shulman, Making Progress: How Eric Bergsten and the Vis Moot Advance the Enterprise of Universal Peace, 24 Pace Int'l L. Rev. 1 (2012).
} 
investigation, communication, counseling, negotiation, familiarity with comparative litigation and alternative dispute resolution processes; organization and management of legal work, and recognition and resolution of ethical dilemmas. ${ }^{3}$ Students have to resolve the dispute between the parties, have to analyze the facts and identify the legal issues, have to find legal rules, cases, and papers to support their arguments, have to understand the facts and ask for clarifications, have to communicate with team members and arbitrators, have to write memoranda for parties which may be considered as written counseling, have to negotiate with team members at various states, have to follow the deadline of submission of memoranda, and have to consider the ethical issues if deciding whether to forge a fact before arbitrators.

The focus of the Moot, i.e., international sales law and international commercial arbitration which are two key themes in international commerce, makes the Moot suitable for developing international commercial lawyers. The Moot presents a problem involved matters that may be resolved by reference to the CISG, and national authorities on the CISG, as well as national authorities on case law. The mock dispute has to be resolved through arbitration applying the rules of a sponsoring arbitration court every year. ${ }^{4}$ Thus the international element of the Moot is clear and makes the Moot relevant to law students who aim to work as international commercial lawyers.

The Moot combines the elements of learning and competition. It has been much debated to balance the two elements. ${ }^{5}$ The education function of international commercial lawyers can at least be seen in the experience of Wuhan University. Most of the students who have participated in the Moot have become arbitration lawyers working with international law firms, or are preparing to do so by attending top law schools around the world, such as in the United States and Hong Kong.

\section{Achievements}

Wuhan University participated in the CIETAC Moot (hosted by China International Economic and Trade Arbitration) in 2002 and won the 3rd prize, and participated in the 10th Willem C. Vis Moot in Vienna in 2003. That was the first effort to know the Moot, which was however interrupted for various reasons. It was felt that Wuhan University had to be more prepared before next participation. The major problem was felt that students were used to learning the theories, but not familiar with the method to apply the doctrines and rules of law to resolve an actual dispute. To write and talk on the legal issues in English further complicated the task. It was not common at that time to require students to read law books in English. Funding was also a problem. Renewed efforts on the Moot have to wait until 2009 when a new Moot team was established. Since then the team has become a star team amongst Chinese and international law schools. The accomplishments are impressive, breaking the record of Chinese law Schools.

In the 2010-2011 Moot, Wuhan University won the 1st runner up for claimant awards in the East Moot (Hong Kong), a major breakthrough in the record of mainland China law schools, and honorable mention for team orals in the Vienna Moot (the 32 teams in the final), very rare for mainland China law schools. In the 2011-2012 Moot, Wuhan University won the award for quarter finalist, best Oralist in the CIETAC Moot, the award for quarter finalists, 1st runner up best Oralist, mention for best Oralist in Moot Shanghai (hosted by Shanghai Arbitration Commission), honorable mention for Respondent Memorandum in East Moot. In 2012-2013, Wuhan University won the award for the semi finalists, best Oralist in all rounds in CIETAC moot, mention for best claimant memorandum in East Moot, honorable mention for best respondent memorandum, honorable mention for team orals in the Vienna Moot. In 2013-2014, Wuhan University won the 1st runner up, best Oralist in all rounds in the CIETAC moot. In 2015-2016, 2016-2017 and 2017-2018 East Moot, Wuhan University successively won the award for eight finalist, quarter finalist and the Neil Kaplan award -best Oralists.

The team members not only have won the honors in the Moot, but also have opened the door to a professional career. Most of them have got offers for further study in top law schools around the world such as Cornell University Law School, Duke University Law School, University of California, Los Angeles School of Law, The University of Texas School of Law, Northwest University Law School, Saarland University Law School, Peking

\footnotetext{
${ }^{3}$ Jack M. Graves, Stephanie A. Vaughan, The Willem C. Vis International Commercial Arbitration Moot: Making the Most of an Extraordinary Educational Opportunity, 10 Vindobona J. of Int'1 Com. L. \& Arb. 173 (2006), 176.

${ }^{4}$ Eric E. Bergsten, Teaching about International Commercial Law and Arbitration: the Eighth Annual Willem C. Vis International Commercial Arbitration Moot, 18 J. of Int'l Arb. 481 (2001), 481.

5 Jeff Waincymer, International and Comparative Legal Education through the William C. Vis Moot Program: A Personal Reflection, 5 Vindobona J. of Int'l Com. L. and Arb. 251 (2001), 273-274.
} 
University, Wuhan University. Many of them are working in leading firms in China and around the world, such as Hogan Lovells Shanghai and Zhonglun Law Firm, or working as in-house counsel for major law firms, such as Dongfeng Motor Corporation, UT M.D. Anderson Cancer Center, and Asia Pacific Dispute Resolution Center.

In 2003 Wuhan University would not have foreseen the accomplishments in less than 10 years. What have been done to make such achievements?

\section{Training}

The Moot team has won amazing honors. Their achievements depend on their personal efforts, as well as the support from the Law School. The support is intellectual, financial, and mental. The Law School has a dedicated coach team. They have developed a whole set of training techniques over the years. Students have to be competent in terms of legal knowledge, English language skills, ability to learn quickly, public speech, team work spirit, and so on. Most of the team members have excellent academic performance, but not necessarily the top in terms of marks. Most of them have been well trained in English, with experiences of studying abroad during the college or high school. Most of them have been trained in the Chinese debating team in terms of public speech and critical thinking. Most of them have been active in interest groups and familiar with communication and organization. The competition is fierce. Often only the elite students can be admitted. The training takes place in two stages. The first is an international commercial arbitration course for around 20 selected students. The second stage is for the moot team of six to eight students selected out of the students attending the course.

\section{A. An International Commercial Arbitration Course}

The course is advertised on the Law School website open to students at all levels, undergraduates and postgraduates. Most applicants are undergraduates, in the 3rd or 4th year. Applicants submit a CV in English and attend an oral interview composed of teachers and past team members. Applicants are required to introduce themselves and state their reasons for application. The students will be selected according to the performance at the oral interview and the CV. Most selected students have a good command of English and a good performance in law. Their backgrounds are diverse and impressive. Many have studied abroad in high school or in college. Some have participated in drama performance, in Chinese or even in Shakespeare drama. Some have won university or national debating competitions in Chinese or in English. Some have been leaders in the students union. The background is important. It seems that students totally engaged and good in the routine course study are not competitive in the Moot selection. The Moot requires the professional knowledge as well as capability in public speech.

Before the course starts the selected students are required to read the past Moot problems and memoranda, textbooks on international commercial arbitration and CISG, such as Redfern and Hunter on International Arbitration, Gary Born's International Commercial Arbitration, and Schlechtriem and Schwenzer's Commentary on the UN Convention on the International Sale of Goods (CISG). Reading the former winning memoranda is aimed at developing the initial impression of writing memoranda. Reading the leading books in the relevant areas is aimed at getting the students to be familiar with the background knowledge involved in the Moot. The presentation of the framework of the subject of international commercial arbitration and CISG is important for later legal research by giving a comprehensive view of the subjects. It is difficult to expect the students to read these works systematically after the Problem is released in October. Students are meanwhile required to practice using the legal database such as Westlaw, Lexis, Kluwer, Heinonline, and so on. The use of databases is essential for writing the memoranda and the oral arguments with the compilation of laws, cases, and journal articles. Students are also required to visit the CISG website maintained by Pace University Law School where one can find anything about the CISG. UNCITRAL website dedicated to arbitration and relevant case law is also recommended to students as a primary source of arbitration law.

The course starts in September shortly before the Moot problem is released. Students are required to read the textbooks on international commercial arbitration before class and make a presentation on a specific topic as they choose during the class. The teacher may interrupt and ask questions. This is aimed at providing students with the background information of international commercial arbitration as well as making the students to practice public speech in English. Reading English textbooks is new in the Law School.

Most students are afraid of reading the heavy law textbooks in English, despite the policy to open bilingual courses and all-English-taught courses in the Law School. In this international commercial law course students must read the English texts and express the thoughts in English otherwise they will not be able to survive the 
selection for the team. Thus there is greater impetus than in other bilingual or all-English-taught courses where the teacher dominates explaining in English and students listen passively. The progress is obvious. Some students start shy and hardly able to talk, and soon come to be confident and able to express in English. The reading and speaking exercise is crucial for later training.

After the Moot problem is released in October the course has a new subject. In addition to the reading and presentation of basic theories on international commercial arbitration, analysis of the Problem is added. Students read the problem before class. The teacher may give a lecture on a specific issue and invite discussion amongst the students. The lecture covers the theories of the matters involved in the case, and the application of the theories in the Problem. The lecturer shows the students how to fit the theories into the fact of the Problem and how to find the theories and doctrines. Students are encouraged to express their thoughts in English. The teacher only guides the students how to read the Problem, establish the arguments, and find literature to support the arguments. Most of the work is done by the students. This is not a normal practice in most lectures in the Law School where students most of the time listen to the teacher on theories or case analysis but do not seek a solution independently.

\section{B. Moot Team Training}

The first selection takes place in early November for participation of the CIETAC moot. CIETAC holds a premoot almost every year in late November since $2000 .{ }^{6}$ Wuhan University has participated in 2002, and since 2010. The selection procedure is also in two parts: a writing sample on one of the issues in the Problem and an oral hearing. The criteria for writing are comprehensive as follows: arguments are persuasive; reasoning is logic and well supported by legislations, cases, and secondary sources; citation is formal; grammar is correct; and writing style is formal. ${ }^{7}$ The second part is a formal oral hearing where students act for claimants and respondents. The criteria follow the Moot criteria in four aspects: (1) Organization and preparation: introduce the issues and facts clearly, present the arguments in an effective sequence, present a persuasive and generalized conclusion. (2) Knowledge of the facts and law: know the facts and law thoroughly; relate the facts to the law so as to make a strong case for client. (3) Presentation: appropriate pace, no mannerism, loud enough, just intonation, eye contact with arbitrators, balance due deference with a forceful and professional argument; tactful under pressure; convincing and persuasive presentation regardless of the merits of the case. (4) Handling questions: answer questions directly and use the questions to turn in favor of clients. ${ }^{8}$

Only 4 to 8 students will pass the strict selection to be team members. The team members have to be totally devoted to the Moot or risk exit. They continue to attend the Course and study in a group when there is no class. The Law School assigns an administrative office for their exclusive use. Writing the first draft starts together with oral training. The training is intensive since the schedule is tight. CIETAC requires both submission of memoranda and oral hearing. That means student have to complete a decent memorandum in less than two months and prepare oral hearing. Each student will be assigned a topic and draft that part. The draft will be compiled by a student who will be responsible for cleaning the style. The draft will be reviewed by the coach team. The students will revise the draft as suggested by the coaches. Meanwhile practice of oral hearing takes place roughly every week. Two students argue for claimant, two students argue for respondent, and three coaches sit as arbitrators. Students are advised in terms of gesture, voice, eye contact, and so on, to be professional. Coaches may interrupt the presentation and ask questions. Students have to answer immediately. It is a mock oral hearing. Sometimes an oral hearing will be arranged with a team in another city or country via skype or qq.

Attending the CIETAC moot is a good opportunity to study and exchange with fellow students in China, and to communicate with lawyers from major law firms in China and abroad. Wuhan University often sends a team of six to eight students. Two act for claimants, and two act for respondents. Others are back up and for study purposes.

See http://cn.cietac.org/Hezuo/index2.asp.

2014 Moot criteria.

2013 Moot criteria, quoted from He Qisheng (ed), International Legal Debating Competition, Language, Skills, and

Rules-The Case of Willemc C. Vis International Commercial Arbitration Moot (Wuhan 2014), 90. 
Coaches and back up students audit each competition and identify the mistakes or shortcomings for improvement. Alongside competition, students have opportunities to exchange with fellow students and arbitrators. Many arbitrators come to seek talents for their law firms. Thus it is a rare chance for students to impress the arbitrators and get access to major law firms. It did happen that a student from Wuhan University was invited to join a major law firm.

After CIETAC students continue training with honors or regrets, but most importantly a clearer direction for improvement. After roughly three month, in March, a second selection may be made after the CIETAC Moot before March when Moot Shanghai, East Moot, Vienna Moot take place, to keep the team competitive. Who will appear in the oral hearing in the Moot depends on their performance during the practice of oral hearing and routine training.

The team will also have one or two guest coaches from abroad, normally for two weeks with each coach. For example, there has been an expert coach in the Moot. Teams she coached have won the first prize, best memorandum, best oralist in the Moot in Vienna. She was impressed by Wuhan University team as arbitrator in the Vienna Moot in 2009 and was happy to coach the team. She has been here twice in 2010 and 2011 and plans to return in 2014. The experienced international coaches bring the insights of the Moot and the new training methods. In particular their common law background is important to teach the case law analysis and the rhetoric questions to Chinese students. They are good at raising questions, and encouraging the students to seek solutions, rather than teaching the textbook theories.

When no guest coach comes the home coach team is a group of professors and former team members. The training is rather informal. Unlike giving lectures, coaches guide and help the team to do research, to look for the authority, to organize the memorandum, to discuss the Problem, and so on. One coach holds a PhD degree from Manchester University Law School. One coach has been visiting professor to Stanford University Law School and Vienna University Law School.

The training schedule is also flexible. The team study and discuss together. The coaches come to help from time to time. The team can go to the coach at his or her convenience. The devotion of coaches is enormous. The training is individual and personal. The team members can raise questions to the coach. The coaches give responses when they find the answer. In addition to providing academic advice, coaches also give mental guidance when the students are in a low mood. Naturally students and coaches develop enduring friendship. Former students come back to coach the team and meet the professor coaches and current students. The advertising event to recruit new course students is often a gathering of former Moot students, even those who have graduated. Moot students who have graduated do return to Wuhan University Law School to give a lecture, or to coach the current team from time to time. It is a close community although dispersed around the world.

The concentration of students on the Moot is not an excuse for performance in other aspects. The students have managed their time well in allocating the time between the Moot and other tasks. They attend the routine class and prepare the exams, in particular in January the exam month. They still get good marks while devoting much of their spare time to the Moot. The Moot experience is an intensive learning process which makes the greatest potential possible of any student. The atmosphere is competitive and friendly. The Moot students are excellent talents and hard-working. Anyone of the team has to catch up with the others.

\section{Thoughts}

It has been proved that legal education through the Moot is an innovative and effective way for training international commercial lawyers. Almost all Moot team members are now engaged in cross-border commercial law business or studies, a high percentage compared with students who have not been involved in the Moot. Many law students become lawyers working mainly on Chinese law, civil servants, or staff in companies. The reasons may be as follows.

First the Moot provide problems which mirrors real international commercial disputes with fact and evidence that are not normally available in textbooks, even case law textbooks. Case law just presents judgments with opinions of the judge, but not evidence or counsel submission put forward by parties. The missing part is however crucial for lawyers. That is how to establish the facts and present the established facts to a court or an arbitral tribunal. The Moot problems are thus valuable teaching materials for developing the abilities to deal with a real case. It provides Moot students with the edge when they apply for a law firm position. 
Second the memorandum writing and oral hearing require students to do research by themselves and find doctrines to raise arguments and support their arguments. Students have to learn a new subject and find the authorities in favour of their arguments. The ability to learn and resolve problems is highly competitive. This stands in contrast with traditional civil law teaching of only doctrines which are not very helpful for lawyers to deal with real world cases.

Third the Moot is an impetus for students to read, think, listen and speak in English. Students have to be buried in the English literature to be able to present their arguments in writing and speaking. They have to read the English textbooks, journals, laws and cases. The huge amount of reading enables them to read fairly fast and understand a lot. Writing memoranda enables the students to use the legal terms, the structure, the style, and the layout of English legal writing. Such requirement is not found in other courses which do not have the competition as pressure and impetus. The course of Legal English is often taught as a general English course. Textbooks are composed of legal texts in English, list of words, and some explanations. The teacher often translates the English texts into Chinese or asks the students to translate. It is the first step to read English legal texts and no more than that for most students. The Moot poses a much higher requirement that Moot students must be able to use the English language in a legal context, rather than just being able to read and understand superficially an English legal text.

Fourth participation in the Moot is a comprehensive training for a successful legal career. Students are required to present their arguments and communicate with arbitrators in a professional way, including professional etiquette and communication. Students have to meet the deadline under pressure. Students have to cooperate in a team. Students have to manage the Moot and other tasks in study or life. These transferable skills are not in the current curriculum of most Chinese law schools but are crucial for a successful lawyer.

Fifth the Moot provides a rare opportunity to meet leading lawyers of international commercial arbitration. Networking with leading lawyers may well lead to internships in major law firms which are not easily available otherwise. In China law firms recruit lawyers from universities where current lawyers have graduate. Most elite law firms are based in Beijing and Shanghai. Students from universities in Beijing and Shanghai have the natural advantage to be admitted because of the alumni resources and geographical facility. How can students from elsewhere go to elite firms? Not easy even for students from top law schools outside Beijing or Shanghai, such as Wuhan University. The Moot gathers the best law school students and the best law firm partners. For example, CIETAC moot gather partners from leading Chinese and international law firms, Junhe, Fangda, King \& Wood Mallesons, Allen \& Overy ,etc. Outstanding students will easily be identified and pursued by leading law firms.

In a word the Moot is an effective way of training international commercial lawyers as has been proved by the years of practice at Wuhan University Law School. Wuhan University Law School will promote the Moot education to more students and to foster more international commercial lawyers. Beneficiaries of the Moot are a minor part of all the Wuhan University Law School students. Wuhan University Law School current has around 200 undergraduates, postgraduates, each year around 20 students are admitted to the international commercial arbitration course, six to eight students admitted to the Moot team and able to attend the oral hearing around the world. It is an urgent task to promote the Moot amongst all the Wuhan University Law School students, at least those who are interested and determined to be an international lawyer. It is a matter of China's national interest to develop international lawyers with China's increasing involvement in the international affairs, political, economic and cultural. Talents in public international law are in need to safeguard China's national interest in international politics.

Talents in private international law including international commercial arbitration are in need to safeguard the interests of Chinese nationals dealing with foreigners in China and abroad. Against this background, the Ministry Education has designated law schools for developing elite international lawyers of which Wuhan University Law School ranks. Training international lawyers has been recognized as a major task for law schools. It is affirmed by the Ministry of Education and Communist Party of China Central Committee of Politics and Law that it is urgent to develop talents able to resolve practical problems and familiar with another subject, in particular developing international lawyers is crucial for developing practice-oriented legal talents and multiple-disciplinary legal talents. International lawyers must be with international vision, familiar with international rules and able to defend the interests of China, in the age of multipolarization, globalization and the opening up of China. 
It is suggested that legal education should be aimed at developing practical abilities and international awareness of talents. To make students familiar with legal practice, law schools should join law firms, courts, procuratorates to develop the course, to give lectures, and provide internship. To develop the international awareness of students, it is suggested Chinese law schools cooperate with overseas leading law schools, such as exchange of teachers and students, and establishment of joint programs. ${ }^{9}$ Wuhan University Law School has been appointed as a key law school for developing practice-oriented legal talents, multi-disciplinary legal talents, and international legal talents.

The barriers are the lack of coaches and the background of students. First, the Moot requires individual teaching and mentoring which makes the greatest progress out of students. If the Moot education is extended to a larger group of students, the individual teaching will be discounted and thus the effect. How to curb this situation if the Moot education is extended to more students? One solution is to train more teachers and even students teaching assistants. Team members can be teaching assistants to help more students to experience the Moot learning style. Second, not all students are competent in reading, writing, thinking, and speaking about the law in the English language. Some may hardly be able to master the English language and may not aim to have a career in foreignrelated legal services. Some may have difficulties, which may be curbed after efforts, to meet the Moot requirement. Thus it is necessary that the Moot education may only extend to students who are qualified in English to an extent, and who are interested in international legal affairs.

It is not necessary that all Wuhan University Law School students go to the official Moot competitions due to personal qualifications, financial support, etc.. But it is possible that Moot competition be held within the Wuhan University Law School, so that more students can compete and make progress. It is desirable that all Wuhan University Law School students experience the learning process provided by the Moot, i.e., to be like a lawyer dealing with real-world-like cases, to think like a lawyer, to research like a lawyer, to write like a lawyer, to argue like a lawyer, and to act like a lawyer. Finally to be a real lawyer. Indeed students are encouraged to participate in various moots and have made outstanding achievements, such as Philip C. Jessup International Law Moot Court Competition, Red Cross International Humanitarian Law Moot, China WTO Moot Court Competition, and International Criminal Court Moot Court Competition.

The Moot education will continue to be a focus of Wuhan University Law School to develop more international lawyers in response to China's increasing demand for international legal talents.

9 The Ministry of Education and Communist Party of China Central Committee of Politics and Law Joint Opinions on Implementing Elite Legal Talents Development Plans, JG [2011] No 10. 